\title{
FROM CANDIDACY TO NEGOTIATIONS: AMENDMENTS IN THE CONSTITUTION OF REPUBLIC OF TURKEY*
}

\author{
Murat T. YÖRÜNG ${ }^{* *}$ \\ Yildiray SAK K** $^{* *}$ \\ Erdem İlker MUTLU ${ }^{* * * *}$
}

\begin{abstract}
1999 Helsinki European Council summit is one of crucial steps in the Turkey-EU relations. Beside other significant points of summit conclusions, Turkey was determined as a candidate state to the EU although it has already been a associated membership. In this context, Turkey, as a candidate state, has begun to make amendments its legal, economical and social life to prepare itself negotiations. The amendments in the legal sphere have pretty fast brought its legal order in line with the EU primary and secondary legal sources. This has made and has been making in two main subtitles: Constitutional amendments and legal harmonization.
\end{abstract}

\section{A. Introduction}

Turkey, as a candidate for accession at the Helsinki European Council in December 1999, entered into a new type of process in the relations between Turkey and the EU. Helsinki became a considerably new landmark by standing near the Association Agreement as an integrating pillar. Turkey prepared its own National Program for the Adoption of the EU acquis in 2001 just after the Accession Partnership and Framework Regulation, which

* The amendments between Article 1-74 in the constitution were analyzed by Yildiray Sak; the amendments between Article 75-174, including final and temporary Articles, were analyzed by Erdem Illker Mutlu. Murat T. Yörüng made all verification and checks in substance.

** Assist. Prof. Dr., Marmara University EC Institute, EU Law Dept.

*** Research Ass., Marmara University EC Institute, EU Law Dept.

**** Research Ass., Marmara University EC Institute, EU Law Dept. 
were adopted by the Council. The most crucial aim of the ongoing process was to remove obstacles before the accession, namely the fulfillment of the Copenhagen political criteria.

The timing was also important for membership because of the dynamic nature of the enlargement of the EU and the timing of the membership depended on whether Turkey would fulfill its commitments in the National Program. Therefore Turkey should have exerted remarkable efforts and so it has done within last four years. The most important of these efforts is the major revision of the Constitution beside the amendments to laws.

We, in this study, examine the constitutionals amendments.

Since 1999 Helsinki summit, the constitution has been amended five times by the Parliament ${ }^{1}$ :

1- Law No. 4709 dated 3.10.2001

2- Law No. 4720 dated 21.11.2001

3- Law No. 4777 dated 27.12.2002

4- Law No. 4841 dated 4.4.2003

5- Law No. 5170 dated 7.5.2004

\section{B. An Analytical Examining on the Constitutional Amendments ${ }^{2}$}

\section{Preamble}

The phrase 'thoughts or opinions' in fifth paragraph of the Constitution has been changed by the phrase 'an activity'. New paragraph is as follow:

"The recognition that no protection shall be accorded to an activity contrary to Turkish national interests; the principle of the indivisibility of the existence of Turkey with its state and territory; Turkish historical and moral values or nationalism; principles, reforms and modernism of Atatürk and that, as required by the principle of secularism, there shall be no interference whatsoever by sacred religious feelings in state affairs and politics;" (Amended: 3.10.2001-4709/1 ) 


\section{Article 10: Equality before the Law}

After first paragraph of the article, following paragraph has been added:

"Women and men have equal rights. The state has to oblige the implementation of this equality." (Added: 7.5.2004-5170/1 .)

Even before that amendment women and men were equal before the law. Therefore it is not a new status for women. Instead of that kind of amendment that repeats the existing legal situation, it should have provided for positive discrimination in favour of women in their daily business and social life.

The EU have a comprehensive action to promote equality in all Community policies, for example equality in the workplace ${ }^{3}$.

\section{Article 13: Restriction of Fundamental Rights and Freedoms}

Ex article was as follows:

"Fundamental rights and freedoms may be restricted by law, in conformity with the letter and spirit of the Constitution, with the aim of safeguarding the indivisible integrity of the State with its territory and nation, national sovereignty, the Republic, national security, public order, general peace, the public interest, public morality and public health, and also for specific reasons set forth in the relevant articles of the Constitution.

General and specific grounds for restrictions of fundamental rights and freedoms shall not conflict with the requirements of the democratic order of society and shall not be imposed for any purpose other than those for which they are prescribed.

The general grounds for restriction set forth in this article shall be applicable to all fundamental rights and freedoms."

New article is as follows:

"Fundamental rights and freedoms may be restricted only by law and in conformity with the reasons mentioned in the relevant articles of the Constitution without infringing upon their essence. These restrictions shall 
not be in conflict with the letter and spirit of the Constitution and the requirements of the democratic order of the societyand the secular Republic and the principle of proportionality." (Amended: 3.10.20014709/1.)

Grounds for general restrictions under the article has been removed: 'the indivisible integrity of the State with its territory and nation, national sovereignty, the Republic, national security, public order, general peace, the public interest, public morality and public health'. They have been replaced by the criteria 'the letter and spirit of the Constitution', 'the requirements of the democratic order of society', 'the secular Republic and 'the principle of proportionality'. Although the criteria 'the secular Republic and 'the principle of proportionality' have already been used by the Constitutional Court as general principles of law, inclusion of the criteria provides legal certainty.

\section{Article 14: Prohibition of Abuse of Fundamental Rights and Freedoms}

Grounds for restrictions under this article have been removed with the exception of "the aim of violating the indivisible integrity of the state with its territory and nation, and endangering the existence of the democratic and secular order of the Turkish Republic based upon human rights'. Additionally, bringing the word 'activity' as being in Preamble, it has broadened the field of rights and freedoms. It would be better if the word had become 'act'; however, suppose that the courts will use method of (objectivist) interpretation when they are applying the article.

\section{Ex article was as follows:}

"None of the rights and freedoms embodied in the Constitution shall be exercised with the aim of violating the indivisible integrity of the State with its territory and nation, of endangering the existence of the Turkish State and Republic, of destroying fundamental rights and freedoms, of placing the government of the State under the control of an individual or a group of people, of establishing the hegemony of one social class over others, of creating discrimination on the basis of language, race, religion or sect, or 
of establishing by any other means a system of government based on these concepts and ideas.

The sanctions to be applied against those who violate these prohibitions and those who incite and provoke others to the same end shall be determined by law.

No provision of this Constitution shall be interpreted in a manner that would grant the right of destroying the rights and freedoms embodied in the Constitution."

New article is as follows:

"None of the rights and freedoms embodied in the Constitution shall be exercised with the aim of violating the indivisible integrity of the state with its territory and nation, and endangering the existence of the democratic and secular order of the Turkish Republic based upon human rights.

No provision of this Constitution shall be interpreted in a manner that enables the State or individuals to destroy the fundamental rights and freedoms embodied in the Constitution or to stage an activity with the aim of restricting them more extensively than stated in the Constitution.

The sanctions to be applied against those who perpetrate these activities in conflict with these provisions shall be determined by law." (Amended: 3.10.2001-4709/3 )

\section{Article 15: Suspension of the Exercise of Fundamental Rights and Freedoms}

The phrase in the second paragraph 'except where death occurs through execution of death sentences' has been removed from text.

Ex article was as follows:

"Even under the circumstances indicated in the first paragraph, the individual's right to life, and the integrity of his or her material and spiritual entity shall be inviolable except where death occurs through lawful 
act of warfare and execution of death sentences; no one may be compelled to reveal his or her religion, conscience, thought or opinion, nor be accused on account of them; offences and penalties may not be made retroactive, nor may anyone be held guilty until so proven by a court judgment."

New article is as follows:

"Even under the circumstances indicated in the first paragraph, the individual's right to life, and the integrity of his or her material and spiritual entity shall be inviolable except where death occurs through lawful act of warfare; no one may be compelled to reveal his or her religion, conscience, thought or opinion, nor be accused on account of them; offences and penalties may not be made retroactive, nor may anyone be held guilty until so proven by a court judgment." (Amended: 7.5.2004$5170 / 2$ )

\section{Article 17: Personal Inviolability, Material and Spiritual Entity of the Individual}

The phrase at the beginning of the last paragraph 'the cases of execution of death penalties under court sentences' has been removed from the text.

Ex paragraph was as follows:

"The cases of carrying out of death penalties under court sentences, the act of killing in self-defense, the occurrences of death as a result of the use of a weapon permitted by law as a necessary measure in cases of:, the execution of warrants of arrest or apprehension, the prevention of escape of lawfully arrested or convicted persons, the quelling of a riot or insurrection, the execution of the orders of authorized bodies during martial law or state of emergency are outside of the provision of paragraph 1."

New paragraph is as follows:

"The act of killing in self-defense, the occurrences of death as a result of the use of a weapon permitted by law as a necessary measure in cases of:, the execution of warrants of arrest or apprehension, the prevention of 
escape of lawfully arrested or convicted persons, the quelling of a riot or insurrection, the execution of the orders of authorized bodies during martial law or state of emergency are outside of the provision of paragraph 1." (Amended: 7.5.2004-5170/3)

\section{Article 19: Personal Liberty and Security}

The custody period in collective crimes, the conditions to inform relatives of the arrested or detained person and right to compensation of persons who arrested and detained unlawfully have been brought in line with the standards of European Convention of Human Rights and European Court of Human Rights' jurisprudence by amending the paragraph 5, 6 and 9.

Ex paragraphs 5, 6 and 9 of the article were as follows:

"5. The person arrested or detained shall be brought before a judge within fourty-eight hours and within fifteen days in the case of offences committed collectively, excluding the time taken to send him to the court nearest to the place of seizure. No one can be deprived of his liberty without the decision of a judge after the expiry of the periods specified above. These periods may be extended during a state of emergency, under martial law or in time of war."

"6. Notification of the situation of the person arrested or detained shall be made to the next of kin, except in cases where definite necessities pertaining to the risks of revealing the scope and subject of the investigation make it compulsory not to comply with this provision."

"9. Damages suffered by persons subjected to treatment contrary to the above provisions shall be compensated for according to law, by the State."

New paragraphs 5, 6 and 9 are as follows:

"5. The person arrested or detained shall be brought before a judge within at latest forty-eight hours and in the case of offences committed collectively within at most four days, excluding the time taken to send the 
individual to the court nearest to the place of arrest. No one can be deprived of his or her liberty without the decision of a judge after the expiry of the periods specified above. These periods may be extended during a state of emergency, under martial law or in time of war." (Amended: 3.10.2001-4709/4)

"6. The arrest or detention of a person shall be notified to next of kin immediately." (Amended: 3.10.2001-4709/4)

"9. Damage suffered by persons subjected to treatment contrary to the above provisions shall be compensated by the State with respect to the general principles of the law on compensation." (Amended: 3.10.20014709/4)

\section{Article 20: Privacy of the Individual's Life}

Last sentence of the first paragraph has been removed and second paragraph has been amended.

Ex article was as follows:

"Everyone has the right to demand respect for his/her private and family life. Privacy of individual and family life cannot be violated. Exceptions necessitated by judiciary investigation and prosecution are reserved.

Unless there exists a decision duly passed by a judge in cases explicitly defined by law, and unless there exists an order of an agency authorized by law in cases where delay is deemed to be prejudicial, neither the person nor the private papers, nor belongings of an individual shall be searched or seized."

New article is as follows:

"Everyone has the right to demand respect for his or her private and family life. Privacy of an individual and family life cannot be violated.

Unless there exists a decision duly passed by a judge on one or several of the grounds of national security, public order, prevention of crime 
commitment, protection of public health and public morality, or protection of the rights and freedoms of others, or unless there exists a written order of an agency authorized by law in cases where delay is deemed to be prejudicial, again on the above-mentioned grounds, neither the person nor the private papers, nor belongings, of an individual shall be searched or seized. The decision of the authorized agency shall be submitted for the approval of the judge having jurisdiction within 24 hours. The judge shall announce his decision within 48 hours from the time of seizure; otherwise, seizure shall automatically be lifted." (Amended: 3.10.2001-4709/5)

\section{Article 21: Inviolability of the Domicile}

Ex article was as follows:

"The domicile of an individual shall not be violated. Unless there exists a decision duly passed by a judge in cases explicitly defined by law, and unless there exists an order of an agency authorized by law in cases where delay is deemed to be prejudicial, no domicile may be entered or searched, and the property therein may not be seized."

New article is as follows:

"The domicile of an individual shall not be violated. Unless there exists a decision duly passed by a judge on one or several of the grounds of national security, public order, prevention of crime commitment, protection of public health and public morals, or protection of the rights and freedoms of others, or unless there exists a written order of an agency authorised by law in cases where delay is prejudicial, again on the above-mentioned grounds, no domicile may be entered or searched or the property therein seized. The decision of the authorized agency shall be submitted for the approval of the judge having jurisdiction within 24 hours. The judge shall announce his decision within 48 hours from the time of seizure; otherwise, seizure shall automatically be lifted." (Amended: 3.10.2001-4709/6) 


\section{Article 22: Freedom of Communication}

Ex article was as follows:

"Everyone has the right to freedom of communication.

Secrecy of communication is fundamental.

Communication shall not be impeded nor its secrecy be violated, unless there exists a decision duly passed by a judge in cases explicitly defined by law, and unless there exists an order of an agency authorized by law in cases where delay is deemed to be prejudicial.

Public establishments or institutions where exceptions to the above may be applied will be defined by law."

New article is as follows:

"Everyone has the right to freedom of communication.

Secrecy of communication is fundamental.

Unless there exists a decision duly passed by a judge on one or several of the grounds of national security, public order, prevention of crime commitment, protection of public health and public morality, or protection of the rights and freedoms of others, or unless there exists a written order of an agency authorized by law in cases where delay is prejudicial, again on the above-mentioned grounds, communication shall not be impeded nor its secrecy be violated. The decision of the authorized agency shall be submitted for the approval of the judge having jurisdiction within 24 hours. The judge shall announce his decision within 48 hours from the time of seizure; otherwise, seizure shall automatically be lifted.

Public establishments or institutions where exceptions to the above may be applied are defined by law." (Amended: 3.10.2001-4709/7)

\section{Article 23: Freedom of Residence and Movement}

Just paragraph 5 of the article has been amended. 
Ex paragraph 5 was as follows:

"A citizen's freedom to leave the country may be restricted because of the national economic situation, civic obligations, or criminal investigation or prosecution."

New article is as follows:

"A citizen's freedom to leave the country may be restricted because of civic obligations, or criminal investigation or prosecution." (Amended: 3.10.2001-4709/8)

\section{Article 26: Freedom of Expression and Dissemination of Thought}

Grounds for restrictions for freedom of expression in second paragraph of the article have been decreased to four, as being suitable the general characteristic of those constitutional amendments. Additionally, paragraph three concerning the prohibition for expression and publishing made other than Turkish language has been removed. Lastly, a new sentence has been added at the end of the article.

Ex paragraph 2 was as follows:

"The exercise of these freedoms may be restricted for the purposes of preventing crime, punishing offenders, withholding information duly classified as a State secret, protecting the reputation and rights and the private and family life of others, or protecting professional secrets as prescribed by law, or ensuring the proper functioning of the judiciary."

New paragraph 2 is as follows:

"The exercise of these freedoms may be restricted for the purposes of protecting national security, public order and public safety, the basic characteristics of the Republic and safeguarding the indivisible integrity of the State with its territory and nation, preventing crime, punishing offenders, withholding information duly classified as a state secret, protecting the reputation and rights and private and family life of others, or 
protecting professional secrets as prescribed by law, or ensuring the proper functioning of the judiciary." (Amended: 3.10.2001-4709/9 )

Repealed paragraph 3 was as follows:

"No language prohibited by law shall be used in the expression and dissemination of thought. Any written or printed documents, phonograph records, magnetic or video tapes, and other means of expression used in contravention of this provision shall be seized by a duly issued decision of a judge or, in cases where delay is deemed prejudicial, by the competent authority designated by law. The authority issuing the seizure order shall notify the competent judge of its decision within twenty-four hours. The judge shall decide on the matter within three days." (Repeal: 3.10.20014709/9)

The sentence added is as follows:

"The formalities, conditions and procedures to be applied in exercising the right to expression and dissemination of thought shall be prescribed by law."(Added: 3.10.2001-4709/9)

\section{Article 28: Freedom of the Press}

Paragraph 2 has been removed:

"Publication shall not be made in any language prohibited by law." (Repealed: 3.10.2001-4709/10)

\section{Article 30: Protection of Printing Facilities}

Ex article was as follows:

"A printing press or its annexes duly established as a publishing house under law shall not be seized, confiscated, or barred from operation on the grounds of being an instrument of crime, except in cases where it is convicted of offences against the indivisible integrity of the State with its 
territory and nation, against the fundamental principles of the Republic or against national security."

New article is as follows:

"Printing facilities, a printing press or its annexes duly established as a publishing house under law shall not be seized, confiscated, or barred from operation on the grounds of being an instrument of crime. " (Added: 7.5.2004-5170/4)

\section{Article: 31 Right to Use Media Other Than the Press Owned by Public Corporations}

Ex second paragraph of the article was as follows:

"The law shall not impose restrictions preventing the public from receiving information or forming ideas and opinions through these media, or preventing public opinion from being freely formed, on grounds other than the general restrictions set forth in Article 13."

New second paragraph is as follows:

"The law shall not impose restrictions preventing the public from receiving information or forming ideas and opinions through these media, or preventing public opinion from being freely formed, on the grounds other than national security, public order, public morals, or the protection of public health." (Amended: 3.10.2001-4709/11 )

\section{Article 33: Freedom of Association}

Ex article was as follows:

"Everyone has the right to form associations without prior permission.

Submitting the information and documents stipulated by law to the competent authority designated by law shall suffice to enable an association to be formed. If the information and documents submitted are found to contravene the law, the competent authority shall apply to the appropriate 
court for the suspension of activities or dissolution of the association in concern.

No one shall be compelled to become or remain a member of an association. The formalities, conditions, and procedures governing the exercise of freedom of association shall be prescribed by law.

Associations may be dissolved or suspended from activity by the decision of a judge in cases prescribed by law. In cases where delay endangers national security or public order and in cases where it is necessary to prevent the perpetration or the continuation of a crime or to affect apprehension, an authority designated by law may be vested with power to suspend the association from activity. The decision of this authority shall be submitted for the approval of the judge in charge within twenty-four hours. The judge shall announce his decision within forty-eight hours. Otherwise this administrative decision shall be annulled automatically.

Provisions of the first paragraph shall not prevent imposition of restrictions on the rights of armed forces and security forces officials and civil servants to the extent that the duties of civil servants so require.

The provisions of this article are also applicable to foundations."

New article is as follows:

"Everyone has the right to form associations, or become a member of an association, or withdraw from membership without prior permission.

No one shall be compelled to become or remain a member of an association.

Freedom of association may only be restricted by law on the grounds of protecting national security and public order, or prevention of crime commitment, or protecting public morality and public health.

The formalities, conditions, and procedures governing the exercise of freedom of association shall be prescribed by law.

Associations may be dissolved or suspended from activity by the decision of a judge in cases prescribed by law. In cases where delay endangers 
national security or public order and in cases where it is necessary to prevent the perpetration or the continuation of a crime or to affect apprehension, an authority designated by law may be vested with the power to suspend the association from activity. The decision of this authority shall be submitted for the approval of the judge in charge within twenty-four hours. The judge shall announce his decision within forty-eight hours. Otherwise this administrative decision shall be annulled automatically.

Provisions of the first paragraph shall not prevent imposition of restrictions on the rights of armed forces and security forces officials and civil servants to the extent that the duties of civil servants so require.

The provisions of this article are also applicable to foundations." (Amended: 3.10.2001-4709/12 )

\section{Article 34: Right to Hold Meetings and Demonstration Marches}

The phrase in last paragraph 'associations, foundations, labour unions, and public professional organizations shall not hold meetings or demonstration marches exceeding their own scope and aims' has been removed, which is most important amendment in this Article.

Ex article was as follows:

"Everyone has the right to hold unarmed and peaceful meetings and demonstration marches without prior permission.

The competent administrative authority may determine a site and route for the demonstration march in order to prevent disruption of order in urban life.

The formalities, conditions, and procedures governing the exercise of the right to hold meetings and demonstration marches shall be prescribed by law.

The competent authority designated by law may prohibit a particular meeting and demonstration march, or postpone it for not more than two months in situations where there is a strong possibility that disturbances may arise which would seriously upset public order, where the requirement of national security may be violated, or where acts aimed at destroying the 
fundamental characteristics of the Republic may be committed. In cases where the law forbids all meetings or demonstration marches in districts of a province for the same reasons, the postponement may not exceed three months.

Associations, foundations, labour unions, and public professional organizations shall nòt hold meetings or demonstration marches exceeding their own scope of activities and their aims."

New article is as follows:

"Everyone has the right to carry out unarmed and peaceful meetings and demonstration marches without prior permission.

The right to hold meetings and demonstration marches shall only be restricted by law on the grounds of national security, and public order, or prevention of crime commitment, public health and public morals or for the protection of the rights and freedoms of others.

The formalities, conditions, and procedures governing the exercise of the right to hold meetings and demonstration marches shall be prescribed by law." (Amended: 3.10.2001-4709/13 )

\section{Article 36: Freedom to Claim Rights}

Right to fair trial has been inserted to the article.

Ex article was as follows:

"Everyone has the right of litigation either as plaintiff or defendant before the courts through lawful means and procedure.

No court shall refuse to hear a case within its jurisdiction."

New article is as follows:

"Everyone has the right of litigation either as plaintiff or defendant and the right to a fair trial before the courts through lawful means and procedures. 
No court shall refuse to hear a case within its jurisdiction." (Amended: 3.10.2001-4709/14)

\section{Article 38: Principles Relating to Offences and Penalties}

The article was as follows before the amendments in 2001 and 2004:

"No one shall be punished for any act which did not constitute a criminal offence under the law in force at the time it was committed; no one shall be given a heavier penalty for an offence than the penalty applicable at the time when the offence was committed.

The provisions of the above paragraph shall also apply to the statute of limitations on offences and penalties and on the results of conviction.

Penalties, and security measures in lieu of penalties, shall be prescribed only by law.

No one shall be held guilty until proven guilty in a court of law.

No one shall be compelled to make a statement that would incriminate himself or his legal next of kin, or to present such incriminating evidence.

Criminal responsibility shall be personal.

General confiscation shall not be imposed as penalty.

The Administration shall not impose any sanction resulting in restriction of personal liberty. Exceptions to this provision may be introduced by law regarding internal order of the Armed Forces.

No citizen shall be extradited to a foreign country on account of an offence."

First amendment in this article had been made in 2001 and following three paragraphs had been added after paragraph 6 .

"Findings obtained through illegal methods shall not be considered as evidence." (Added: 3.10.2001-4709/15 )

"No one shall be deprived of his liberty merely on the ground of inability to fulfil a contractual obligation." (Added: 3.10.2001-4709/15 ) 
"The death penalty shall not be imposed excluding the cases in time of war, imminent threat of war and terrorist crimes." (Added: 3.10.20014709/15 )

Then, second amendment in this article has been made in 2004. Paragraph 9 has been removed from the article and paragraph 10 and last paragraph have been amended.

"The death penalty shall not be imposed excluding the cases in time of war, imminent threat of war and terrorist crimes." (Repeal: 7.5.20045170/5)

"General confiscation and death penalty shall not be imposed." (Amended: 7.5.2004-5170/5 )

"No citizen shall be extradited to a foreign country on account of an offence except obligations originating from being party to the International Criminal Court." (Amended: 7.5.2004-5170/5)

\section{Article 40: Protection of Fundamental Rights and Freedoms}

Following paragraph has been added to the article as a second paragraph:

"The State is obliged to indicate in its transactions the legal remedies and authorities that the persons concerned should apply and their time limits." (Amended: 3.10.2001-4709/16)

\section{Article 41: Protection of the Family}

Ex paragraph 1 of the article was as follows:

"The family is the foundation of Turkish society."

New paragraph 1 is as follows:

"The family is the foundation of the Turkish society and is based on equality between the spouses." (Amended: 3.10.2001-4709/17) 


\section{Article 46: Expropriation}

Ex article was as follows:

"The State and public corporations shall be entitled, where the public interest requires it, to expropriate privately owned real estate wholly or in part or impose administrative servitude on it in accordance with the principles and procedures prescribed by law, provided that compensation is paid in advance.

The method and procedure for calculating compensation for expropriation shall be prescribed by law. In determining the compensation, the law shall take into account tax declarations, current value established by official assessment at the time of expropriation, unit prices and construction costs for real estate, and other objective criteria.

The procedure for taxing the difference between the sum due in compensation and the value declared in the tax declaration shall be prescribed by law.

Compensation shall be paid in cash and in advance. However, the procedure to be applied in paying compensation for land expropriated in order to carry out land reform, major energy and irrigation projects, and housing and resettlement schemes and afforestation, and to protect the coasts and to build tourist facilities shall be regulated by law. In the previous cases where the law may allow payment in installments, the payment period shall not exceed five years; whence payment shall be made in equal installments and an interest whose rate is equivalent to the highest interest paid on the public debt shall be paid for the remainder of installments.

Compensation for land expropriated from the small farmer who cultivates his own land shall in all cases be paid in advance."

New article is as follows:

"The State and public corporations shall be entitled, where the public interest requires, to expropriate privately owned real estate wholly or in part and impose administrative servitude on it, in accordance with the 
principles and procedures prescribed by law, provided that the actual compensation is paid in advance.

The compensation for expropriation and the amount regarding its increase rendered by a final judgment shall be paid in cash and in advance. However, the procedure to be applied for compensation for expropriated land in order to carry out land reform, major energy and irrigation projects, and housing and resettlement schemes and afforestation, and to protect the coasts and to build tourist facilities shall be regulated by law. In the cases where the law may allow payment in installments, the payment period shall not exceed five years, whence payments shall be made in equal installments.

Compensation for the land expropriated from the small farmer who cultivates his own land shall in all cases be paid in advance.

An interest equivalent to the highest interest paid on public claims shall be implemented in the installments envisaged in the second paragraph." (Amended: 3.10.2001-4709/18)

\section{Article 49: Right and Duty to Work}

Paragraph 2 of the article has been amended and last paragraph has been removed.

Ex article was as follows:

"Everyone has the right and duty to work.

The State shall take the necessary measures to raise the standard of living of workers, to protect them in order to improve the general conditions of labour, to promote labour, and to create appropriate economic conditions for prevention of unemployment.

The State shall take facilitating and protecting measures in order to secure labour peace in worker-employer relations." 
New paragraph 2 is as follows:

"The State shall take the necessary measures to raise the standard of living of workers, and to protect workers and the unemployed in order to improve the general conditions of labour, to promote labour, to create appropriate economic conditions for prevention of unemployment and to secure labour peace." (Amended: 3.10.2001-4709/19)

"The State shall take facilitating and protecting measures in order to secure labour peace in worker-employer relations." (Repealed: 3.10.20014709/19)

\section{Article 51: Right to Organize Labour Unions}

Ex Article was as follows:

"Workers and employers have the right to form labour unions and employers' associations and higher organizations, without prior permission, in order to safeguard and develop their economic and social right and the interests of their members in their labour relations.

In order to form unions and their higher bodies, it shall suffice to submit the information and documents prescribed by law to the competent authority designated by law. If this information and documentation is not in conformity with law, the competent authority shall apply to the appropriate court for the suspension of activities or the dissolution of the union or the higher body.

Everyone shall be free to become a member of or withdraw from membership in a union.

No one shall be compelled to become a member, remain a member, or withdraw from membership of a union.

Workers and employers cannot hold concurrent membership in more. than one labour union or employers' association.

Employment in a given workplace shall not be made conditional on being, or not being, a member of a labour union. 
To become an executive in a labour union or in higher organizations of them it is a prerequisite condition that the workers should have held the status of a labourer for at least ten years.

The status, the administration, and the functioning of the labour unions and their higher bodies should not be inconsistent with the characteristics of the Republic as defined in the Constitution, or with democratic principles."

New article is as follows:

"Employees and employers have the right to form labour unions employers' associations and higher organizations, without permission, and they also possess the right to become a member of a union and to freely withdraw from membership, in order to safeguard and develop their economic and social rights and the interests of their members in their labour relations. No one shall be forced to become a member of a union or to withdraw from membership.

The right to form a union shall solely be restricted by law and with the purposes of safeguarding national security and public order and to prevention of crime commitment, protection of public health and public morals and the rights and freedoms of others.

The formalities, conditions and procedures to be applied in exercising the right to form union shall be prescribed by law.

Membership in more than one labour union cannot be obtained at the same time and in the same work branch.

The scope, exceptions and limits of the rights of civil servants who do not have a worker status are prescribed by law in line with the characteristics of their job.

The regulations, administration and functioning of labour unions and their higher bodies should not be inconsistent with the fundamental characteristics of the Republic and principles of democracy." (Amended: 3.10.2001-4709/20) 


\section{Article 55: Guarantee of Fair Wage}

Ex last paragraph of the article was as follows:

"In determining the minimum wage, the economic and social conditions of the country shall be taken into account."

New last paragraph:

"In determining the minimum wage, the living conditions of the workers and the economic situation of the country shall be taken into account." (Amended: 3.10.2001-4709/21)

\section{Article 65: The Extent of Social and Economic Rights}

Ex Article was as follows:

"The State shall fulfil its duties as laid down in the Constitution in the social and economic fields within the limits of its financial resources, taking into consideration the maintenance of economic stability."

New article is as follows:

"The State shall fulfil its duties as laid down in the Constitution in the social and economic fields within the capacity of its financial resources, taking into consideration the priorities appropriate for the aims of these duties." (Amended: 3.10.2001-4709/22).

\section{Article 66: Turkish Citizenship}

Last sentence of paragraph 2 of the article has been repealed.

Ex paragraph 2 was as follows: 
"The child of a Turkish father or a Turkish mother is a Turk. The citizenship of a child of a foreign father and a Turkish mother shall be defined by law."

The second sentence has been repealed in the new paragraph 2 . (Repealed 3.10.2001-4709/23)

\section{Article 67: Right to Vote, to be Elected and to Engage in Political Activity}

Paragraph 5 of the article has been amended and a sentence has been added to the end of the article.

Ex paragraph 5 was as follows:

"Privates and corporals serving in the armed services, students in military schools, and convicts in penal execution may not vote. The Supreme Election Council shall determine the measures to be taken to ensure the safety of the voting and counting of votes when those under arrest vote in penal institutions or prisons; such voting shall be done under the direction and supervision of authorized judge."

New paragraph is as follows:

"Privates and corporals serving in the armed services, students in military schools, and convicts in penal execution excluding those convicted of negligent offences may not vote. The Supreme Election Council shall determine the measures to be taken to ensure the safety of the voting and counting of votes in penal institutions or prisons; such voting shall be done under the direction and supervision of authorized judge." (Amended: 3.10.2001-4709/24)

"The amendments made in the electoral laws shall not be applied to the elections to be held within a year from when the amendments enter into force." (Added: 3.10.2001-4709/24) 


\section{Article 69: Principles to be Regarded by Political Parties}

According to ex paragraph 6 of the Article, a political party deeming to become the centre of actions defined in paragraph 4 of article 68 is dissoluted permanently. Adding a sentence of this paragraph, the concept of 'becoming centre' has been explained and, thus, risk for its using by Constitutional Court with a wider meaning in judgments is prevented.

Secondly, after this paragraph, a new paragraph has been added in order to provide the court with an alternative sentence other than dissolution of political parties.

Finally, last paragraph of the article has been amended.

Ex paragraph 6 was as follows:

"The decision to dissolve a political party permanently owing to activities violating the provisions of the fourth paragraph of Article 68 may be delivered only when the Constitutional Court determines that the party in question has become a centre for the execution of such activities."

New sentence added to the end of the paragraph is as follows:

"A political party shall be deemed to become the centre of such actions only when such actions are executed intensively by the members of this party or the situation is shared implicitly or explicitly by the grand congress, general chairperson or the main decision-making or administrative organs of this party or by the group's general meeting or group executive board at the Turkish Grand National Assembly or when these activities are carried out by the above-mentioned party organs directly." (Added: 3.10.2001-4709/25)

Dissoluting a political party by reason of objectives and statements in its statue, unless these objectives and statements are not put in action, may not be acceptable. European legal order in this context that Turkey try to obey is directed and dominated by the Strassbourg Court. According to wellestablished case law of the Court, though there is power of appreciation in the State side, it is not unlimited, and it is for the Court to supervise whether a restriction is compatible with the Convention ${ }^{4}$. So, due to the flue wording 
of the above-article and the theory of 'the margin of appreciation' of the Court, the decisions may be incurred the intervention of the Court.

New paragraph 7 is as follows:

"The Constitutional Court may deliver a decision depriving a political party to be deprived of State aid wholly or partly with respect to strength of the actions brought before the court instead of dissolving it permanently in accordance with the above-mentioned paragraphs." (Added: 3.10.20014709/25)

Ex last paragraph of the article was as follows:

"The establishment and activities of political parties, their supervision and dissolution and the election expenses and procedures of the political parties and candidates are regulated by law in accordance with the abovementioned principles."

New last paragraph is as follows:

"The establishment and activities of political parties, their supervision and dissolution, their deprival of State aid wholly or partly, the election expenses and procedures of the political parties and candidates, are regulated by law in accordance with the above-mentioned principles." (Amended: 3.10.2001-4709/25)

\section{Article 74: Right to Petition}

Ex article was as follows:

"Citizens have the right to apply in writing to the competent authorities and to the Turkish Grand National Assembly with regard to requests and complaints concerning themselves or the public.

The result of the application concerning himself shall be made known to the petitioner in writing.

The way of exercising this right shall be determined by law."

New article is as follows: 
"Citizens, and foreigners resident in Turkey under the principle of reciprocity have the right to apply in writing to the competent authorities and to the Turkish Grand National Assembly with regard to the requests and complaints concerning themselves or the public.

The result of the application concerning himself shall be made known to the petitioner in writing without delay.

The way of exercising this right shall be determined by law." (Amended: 3.10.2001-4709/26)

\section{Article 78 Deferment of Elections}

The former article was as follows ${ }^{5}$ :

"If the holding of new elections is found impossible because of war, the Turkish Grand National Assembly may decide to defer elections for a year.

If the grounds for deferment do not disappear this measure may be repeated under the procedure for deferment.

By-elections shall be held when vacancies arise in the membership of the Turkish Grand National Assembly. By-elections shall be held once in every election term and cannot be held until 30 months have elapsed from the date of the previous general elections. However, in cases where the number of vacant seats reaches five percent of the total number of seats, by-elections shall be held within three months.

By-elections shall not be held within one year before general elections."

By the amendment legislation number 4777 on 27.12.2002, the following paragraph has been added:

"Apart from the abovementioned cases, if one of the provinces or election regions remains without a representative in the Turkish Grand National Assembly, there will be by-election on the first Sunday following 90 days after the seat is emptied. The elections under this paragraph are not subject to the application of Article 127 paragraph 3 of the Turkish Constitution." 6 


\section{Article 86: Salary and Allowances}

Another amendment in this chapter is Article 86. This article regulates the salaries, allowances also covering travel reimbursements and refunds of MPs. The article is read as follows:

"The salaries, allowances and retirement arrangements of the members of the Turkish Grand National Assembly shall be regulated by law. The monthly amount of the salary shall not exceed the salary of the most senior civil servant; the travel allowance shall not exceed half of that salary. The members of the Turkish Grand National Assembly and its retirees are affiliated with the Pension Fund of the Turkish Republic, and the affiliation of those continue upon their will in case their membership expires.

The salaries and allowances paid to the members of the Turkish Grand National Assembly shall not necessitate the suspension of payments of pensions and similar benefits by the Pension Fund of the Turkish Republic.

A maximum of three months' salaries and allowances may be paid in advance." (Amended: 21.11.2001-4720/1)

The amendment in this article is the inclusion of 'pension rights' under the provision that used to regulate salaries and allowances. The former article did not include phrase '.. and retirement arrangements..' in the first sentence. Consequently, the earlier form of the article was not attached with the last sentence of the first paragraph, which provides affiliation with the Pension Fund of the Turkish Republic.

\section{Article 87: The Functions and Powers of Turkish Grand National Assembly}

Article 87 also was subject to change under the amendment package in 2001. The article is read as follows:

"The functions and powers of the Turkish Grand National Assembly comprise the enactment, amendment, and repeal of laws; the supervision of the Council of Ministers and the Ministers; authorisation of the Council of Ministers to issue governmental decrees having the force of law on certain 
matters; debating and approval of the budget draft and the draft law of the final accounts, making decisions regarding the printing of currency and declaration of war; ratifying international agreements, deciding with the three fifth's of the Turkish Grand National Assembly on the proclamation of amnesties and pardons of the Constitution; confirming death sentences passed down by the courts; and exercising the powers and executing the functions envisaged in the other articles of the Constitution." 3.10.2001-4709/28)

The former article had two main different points. The first was the exclusion of prisoners sentenced as a result of actions under article 14 of the Constitution from the amnesties. By this amendment, under this article, there is no exception for amnesties. Second point subject to change was the decision to execute death penalties. Since the death penalties are totally abolished, there is no application of executing them.

\section{Article 89: Promulgation of Laws by the President of The Republic of Turkey}

Article 89 was changed under the same amendment package.

The article is read as follows:

"The President of the Republic shall promulgate the laws adopted by the Turkish Grand National Assembly within fifteen days.

He shall, within the same.period, refer to the Turkish Grand National Assembly for further consideration, laws which he deems wholly or in part or unsuitable for promulgation, together with a statement of his reasons. In the event of being deemed unsuitable by the President, the Turkish Grand National Assembly may only discuss those articles deemed to be unsuitable. Budget laws shall not be subjected to this provision.

Provisions relating to Constitutional amendments are reserved."9 (Amended: 3.10.2001-4709/29) 
In the former article there was no separation between partial and full promulgation of the laws in terms of the action taken by the president. The new form of the article leaves a space which is more efficient for the lawmaking process and avoiding unnecessary suspensions.

\section{Article 90: The ratification of International Treaties}

Article 90, which provides ratification and enforcement of international agreements in internal legal system, has also been amendment.

The article was read as follows:

"The ratification of treaties concluded with foreign states and international organisations on behalf of the Republic of Turkey, shall be subject to adoption by the Turkish Grand National Assembly by a law approving the ratification.

Agreements regulating economic, commercial and technical relations, and covering a period of no more than one year, may be put into effect through promulgation, provided they do not entail any financial commitment by the state, and provided they do not infringe upon the status of individuals or upon the property rights of Turkish citizens abroad. In such cases, these agreements must be brought to the knowledge of the Turkish Grand National Assembly within two months of their promulgation.

Agreements in connection with the implementation of an international treaty, and economic, commercial, technical, or administrative agreements which are concluded depending on an authorisation given by law shall not require approval by the Turkish Grand National Assembly. However, agreements concluded under the provision of this paragraph and affecting the economic or commercial relations and private rights of individuals shall not be put into effect unless promulgated.

Agreements resulting in amendments to Turkish laws shall be subject to the provisions of the first paragraph. 
International agreements duly put into effect carry the force of law. No appeal to the Constitutional Court can be made with regard to these agreements, on the ground that they are unconstitutional."10

The new last paragraph provides discrimination between the international agreements on the grounds whether they grant fundamental rights or provide human rights or not. If an international agreement provides human rights or fundamental rights, it has certain supremacy when compared with other rules, which were referred to in the previous paragraph.

In international law there are traditionally, mainly two approaches to the relationship between international law and national law: the 'monist' and the 'dualist' theories. By this means, the question appears as whether or not rule of an international law applies as such in national law. However, in some cases, there are intermediate forms, and among some European States there are three different approaches.

The first category of states such as Belgium, Netherlands and France, an agreement of international law entered into force by the state duly approved in the international plane automatically becomes part of the law of the state without a need to 'incorporate' or 'transform' by a separate act.

The second category of states such as Germany and Italy, an international agreement requires a separate legislative act to give effect to the international agreement in internal law. When the authorities pass such an act, there is no need for a further action and the international agreement in question is applicable in internal law.

The third category of states such as the UK and Denmark, there is strictly a need for a transformation process. The only way to give effect to an international agreement is by a national rule, which purports to incorporate the international agreement.

The dualist approach is a conclusion of theories defended by Anzilotti, Kelsen, Triepel. At that time international law was more or less dealing with inter-state matters, however, nowadays, it has begun to deal with intra-state matters. This process of evolution also has become appropriate to be used as a justification of dualist approach whereas national parliaments see 
themselves as the sole defender of amending the international agreements meeting the current necessities of the community.

There are two categories of arguments supporting the dualist approach. The first group is the approach derived from democratic principles and the second one is the approach that desire of a state to modify the international agreement as it fits the effect of international agreement in the national legal system. The first approach which requires the democratic participation of the national parliaments in the decision making process of international agreements is less feasible. However, the arguments in the second category are doubtful so that they provide direct or indirect derogations from international undertakings. The proper way of derogations are subject to be negotiated during the decision making process of international agreements and have to be regulated under reservation clauses rather than through back door operations.

In Turkish constitution, the case is simpler in a sense with reference to the non-dualist influence. On the other hand, there is a complexity as a result of ambiguity in the context of article 90 . Article 90 does not pronounce on the hierarchy of international agreements compared with the rules in national legal system. The second paragraph sets forth rule of judicial review that prohibits bringing international agreements before adjudication on the grounds that they conflict with the Turkish Constitution. This is a built in guarantee for the obligations undertaken by Turkish State under international law avoiding actions under the intention of a back door exit from the responsibility under 'pacta sund servanda'. However, the hurdle on the way to constitutional exit does not show up in the parliamentary participation conferring a compulsory ratification procedure for some certain international agreements. Before evaluating the new form, it is necessary to make a comparative understanding of the limits of the scope of direct applicability under the context of two different systems. The first is the case in the European Union and the second is the case in UK whereas in both cases the activist courts survived face against the necessities of incorporating with international agreements.

In the European Union, the legal effects of international agreements are closely tied with the casuistic settlements of ECJ by virtue of a possible question raised before the court. The reason for the use of this way is the non-existence of rules regulating the effect of international legal instruments 
in community law under the Treaties. Certainly, what 'legal instruments of international law' mean refers the instruments where the EC has a 'party' standing. Articles 281 (ex Article 210) and 300 (ex Article 228) provide the Community legal personality and power to enter into contractual relations with other persons and organizations. As it has been the case in States, in the legal order of the EU, the question concentrates on whether these international agreements may be subject to 'direct effect' doctrine or not. Furthermore, is the status of these agreements admitted before the ECJ equal to the status of same type of agreements before national courts? ${ }^{11}$

Firstly, these agreements could be evaluated as traditional international agreements, which have a binding effect only on the States, and organizations, which are parties. There is no specific effect on individuals. Secondly, agreements entered by the Community sharing some of the specific characteristics of EC law could particularly direct effect. There are number of court decisions on the subject in which it was provided that under some circumstances these agreements could be held as having direct effect. However, for many lawyers relying on the application of supreme rules equally in every case, it was frustrating to observe that the Court brought political considerations upon these rulings rather than the legal criteria considered in Van Gend En Loos. Two cases have significant importance. In the first one, the question raised was whether the provisions of the General Agreement on Trade and Tariffs (GATT) 1947 and the successor World Trade Organization Agreement may have direct effect or not. In the second case, namely International Fruit Company case, a Dutch court made a preliminary reference questioning whether it had jurisdiction to rule on the validity of Community regulations in connection with international law. The Court concluded that in terms of the criteria laid down in earlier cases, the provisions of GATT were not sufficiently precise and unconditional meeting the requirements of having direct effect. In Hauptzollamt Mainz v. Kupferberg the ECJ ruled that the provision of Portuguese free trade agreement had direct effect considering the fact that the provision in question was unconditional, precise and its direct application was within the purpose of the agreement.

There is no uniform application of 'direct effect doctrine' within the context of EC law, which could be observed as an ongoing experiment of judicial decision-making in integration process. However, the same is true 
for many States. Even there were examples like the United Kingdom, which could never be overcoming the problem arising from a constitutional principle, States that have vague regulations like Turkey had to find a solution. The case for UK was a conflict of constitutional rules with supreme Community legislation after full membership. The British incorporation to EC law had become a painful period with the examination of 1972 EC Act before national courts. Since the concept "direct effect" of international agreements could only be a spelling error in the UK, the principle of 'sovereignty of parliament' was a serious hurdle, which avoids this type of acts binding the future parliaments to be in force consistent with this constitutional principle. The 1972 EC Act provided all secondary legislation enacted by EC Institutions to be directly applicable in internal law of the United Kingdom without any need for further act of the Parliament for the purpose of incorporating EC law. There had been a process of conflict between the constitutional point prohibiting any act of the Parliament binding the future Parliaments and the 1972 EC Act. Consequently, in Shields vs. Coomes it was contended that the 1972 EC Act, which provided direct applicability as the supreme EC law, requires is in conflict with the constitutional point 'sovereignty of Parliament'. ${ }^{12 \mathrm{ii}}$ In McCarthy vs. Smith there has been a 'reconciliation' of Parliamentary Sovereignty with the supremacy of EC Law. Lord Denning viewed a teleological approach to $1972 \mathrm{EC}$ Act as a fulfilment of obligations arising from international law.

The position taken in Turkish Constitution is slightly different. Neither of the abovementioned positions are taken within the new form of Article 90. The earlier form of Article 90 had ambiguous wording for the determination of Turkish approach to national law-international law relations, even it was certain that the rules were not tough as they are in the UK. In the new form of Article 90 of Turkish Constitution there is a clarified hierarchy between the international agreements providing fundamental rights and freedoms and national legislation. In the literal meaning of the new form of Article 90, the hierarchical ranking provides supremacy and direct applicability for the international agreements, which grant fundamental rights and freedoms. Consequently, in case of a possible conflict of the international agreement of an abovementioned type with internal legislation, a Turkish judge has to pertain the below mentioned test in order to apply this provision: 
-if there is a dispute arising from conflicting provisions of national law and international agreement

-if there is a conflict on the same subject

-if the international agreement is of a type granting fundamental rights and freedoms.

As the test considered that new form is formulated as follows:

“...

In the event of a dispute arising from the difference on the same subject in the provisions of international agreements regulating fundamental rights and freedoms and the national legislation, provisions of international agreements will be applicable." ${ }^{13}$ (Amended: 7.5.2004- 5170)

It seems that the new form of the article strictly underlines the nonapplicability of international agreements, which are in the second group containing no fundamental rights and freedoms directly in a matter of a possible dispute with a provision of national law. This expression, nevertheless, avoids the unnecessary debate on the existence of direct applicability principle within the context of international agreements in conflict with provisions of national law.

\section{Article 94: Office of Speaker}

Article 94 has an amendment in terms of utilizing the administrative mechanism of Turkish Parliament. The new article has an amended fourth paragraph which stipulates the procedure of elections for the Office of Speaker.

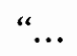

The candidates from among the members of the Assembly for the Office of the Speaker of the Turkish Grand National Assembly shall be announced, within five days of the convening of the Assembly, to the Bureau of the Assembly. Election of the Speaker shall be held by secret ballot. In the first 
two ballots, a two-thirds majority of the total number of members, and in the third ballot an absolute majority of the total number of members is required. If an absolute majority cannot be obtained in the third ballot a fourth ballot shall be held between the two candidates who have received the highest number of votes in the third ballot; the member who receives the greatest number of votes in the fourth ballot shall be elected Speaker. The election of the Speaker shall be completed within five days of the expiry of the period for the nomination of candidates.

..."14 (Amended: 3.10.2001-4709/30)

\section{Article 100: Parliamentary Investigation}

Article 100 also has an amendment. The article provides for the Parliamentary investigation concerning the Prime minister and the ministers. This article is amended to increase the effectiveness of fighting with corruption. The new form of the Article is as follows:

"Parliamentary investigation concerning the Prime Minister or other ministers may be requested through a motion tabled by at least one-tenth of the total number of members of the Turkish Grand National Assembly. The Assembly shall consider and decide on this request with a secret ballot within one month at the latest.

In the event of a decision to initiate an investigation, this investigation shall be conducted by a commission of fifteen members chosen by lot on behalf of each party from among three times the number of members the party is entitled to have on the commission, representation being proportional to the parliamentary membership of the party. The commission shall submit its report on the result of the investigation to the Assembly within two months. If the investigation is not completed within the time allotted, the commission shall be granted a further and final period of two months. At the end of this period, the report shall be submitted to the Office of the Speaker of the Turkish Grand National Assembly.

Following its submission to the Office of the Speaker of the Turkish Grand National Assembly, the report shall be distributed to the members within ten days and debated within ten days after its distribution and if necessary, a decision may be taken to bring the person involved before the 
Supreme Court. The decision to bring a person before the Supreme Court shall be taken by a secret ballot only by an absolute majority of the total number of members.

Political party groups in the Assembly shall not hold discussions or take decisions regarding parliamentary investigations." 15 (Amended: 3.10.2001-4709/31)

\section{Article 149: Functions and Trial Procedure of the Constitutional Court}

The next Article subject to amendment is Article 149. Ex first paragraph was as follows:

The Constitutional Court shall convene with its President and ten members, and shall take decisions by absolute majority. Decision of annulment of Constitutional amendments shall be taken by a two-thirds majority.

The paragraph has been amended and the sentence 'dissolution in the cases of political parties' was added to the second sentence as another case for two-thirds majority. (Amended: 3.10.2001-4709/33)

\section{Article 160: Court of Audit}

Article 160 also has a considerable amendment in terms of democratisation of laws. The article is read as follows:

"The Audit Court shall be charged with auditing, on behalf of the Turkish Grand National Assembly, all the accounts relating to the revenue, expenditure and property of government departments financed by the general and subsidiary budgets, with taking final decisions on the acts and accounts of the responsible officials, and with exercising the functions required of it by law in matters of inquiry, auditing and judgment. Parties concerned may file a single request for reconsideration of a final decision of the Audit Court within fifteen days of the date of written notification of the 
decision. No applications for judicial review of such decisions shall be filed in administrative courts.

In the event of a dispute between the Council of State and the Audit Court concerning decisions on matters of taxation or similar financial obligations and duties, the decision of the Council of State shall take precedence.

The organisation, functioning and auditing procedure of the Audit Court, the qualifications, appointment, duties and powers, rights and obligations of its members, other matters relating to their personal status, and the security of tenure of the president and members shall be regulated by law."

The former article contained the exception for the audit of the property in possession of the armed forces in the last paragraph. The last paragraph was as follows:

"The procedure for auditing, on behalf of the Turkish Grand National Assembly, of state property in possession of the Armed Forces shall be regulated by law in accordance with the principles of secrecy required by national defence." (Repealed: 7.5.2004-5170/9 md)

This amendment also provided a more democratic understanding of audit exercise which abolished discrimination in favour of army possessed property.

\section{Article 169 Protection and Developments of The Forests}

The earlier form of the second paragraph of the Article 169 was as follows:

The ownership of state forests shall not be transferred to others. state forests shall be managed and exploited by the state in accordance with the law. Ownership of these forests cannot be acquired through prescription. 
nor shall servitude other than that in the public interest be imposed in respect of such forests.

$\ldots, 16$

The second paragraph has an additional word in the second sentence whereas it is stated that "...State forest shall be managed and exploited or let be exploited by the state in accordance with the law." This amendment gives an opportunity for the non-state bodies the exploitation under the control of state. (Amended: 7.5.2004-5170/9 md)

\section{Article 170 Protection of the Inhabitants of the Forest Villages}

Article 170 has also an amendment.

"Measures shall be introduced by law to secure co-operation between the state and the inhabitants of villages located in or near forests in the supervision and exploitation of forests for the purpose of ensuring their conservation and improving the living conditions of their inhabitants; the law shall also regulate the development of areas which technically and scientifically ceased to be forests before 31 December 1981, the identification of areas whose preservation as forest is considered technically and scientifically useless, their exclusion from forest boundaries, their improvement by the state for the purpose of settling all or some of the inhabitants of forest villages in them, and their allocation to these villages.

The state shall take measures to facilitate the acquisition, by these inhabitants, of farming equipment and other inputs.

The land owned by villagers resettled outside a forest shall immediately be reafforested as a state forest."

The following paragraph / phrase is added: after the first sentence of the article in the ex form:

"the identification of areas whose preservation as forest is considered technically and scientifically useless, their exclusion from forest boundaries, their improvement by the state for the purpose of settling all or some of the 
inhabitants of forest villages in them, and their allocation to these villages will be done by the State." 17

The purpose of this amendment was to leave the state an implementation power of the transfer of exploitation of forest areas. The discretionary right of the state on this field is widened in a sense.

\section{Amendments to Provisional Articles}

The provisional change for the Law 4709 adopted on 3.10.2001

Provisional Article A:

Amendments under articles 24 and 67 shall not be applied in the next election.

Provisional Article B:

The amendments made in Articles 28 and 67 of the constitution is not applied for the acts committed under article 14 of the Turkish Constitution before entry into force of this change

The provisional change for the law 4777 adopted on 27.12 .2002

\section{Provisional Article 1:}

The amendment under Article 67 last paragraph of the Turkish Constitution is not applicable to the first election to be held in the 22 nd term of Turkish Grand National Assembly.

Provisional Article 15:

The last paragraph of the provisional article 15 is abolished. The earlier form of the Article gives possibility of immunity to the laws and decree laws from constitutional review which were enacted by the provisional administration of National Security Council in the period after 12 th of September 1980. The new form of the article does not contain this immunity which makes constitutional review possible on these acts as well. 
This is a more legitimate and democratic approach when compared with the former Article.

\section{Endnotes}

${ }^{1}$ Full texts of the laws amending the constitution can be found in the following site: http://www.tbmm.gov.tr/develop/owa/kanunlar.sorgu_baslangic

${ }^{2}$ For the old forms of the articles of the constitution, following sources have been used: http://www.yargitay.gov.tr/bilgi/kanun liste/PC12709.HM5.frameset.html; http://www.constitution.org/cons/turkey/*.html ;

http://www.anayasa.gov.tr/engconst/const.htm ; Proposal for Constitution of Republic of Turkey, 2001, second ed., Turkish Bar Association, 2003. Some of the translations, in especially the old forms of the articles, are quoted from the original abovementioned sources. The others, which fall outside of the latter, are made by the author.

${ }^{3}$ The European Court of Justice (ECJ) has also stated that equal treatment between men and women is a fundamental one in the Community leagal order (Case C50/96, Deutcshe Telekom v. Schroder [200] ECR I-743, para.19). Furthermore, after Maatricht and Amsterdam Treaty, which have given necessary competence to the EU institutions, the Council established a four year program on gender equality for 2001-2005 (Council Decision 2001/51) and, subsequently Commission adopted for working programs for this period.

${ }^{4}$ See. Case of Open Door and Dublin Weel Women v. Ireland, 29.10.1992, Series A-246 A, para. 68; Case of United Communist Part v. Turkey, 30.01.1998, Series 1998-I, para. 27,46

${ }^{5}$ http://www.anayasa.gov.tr/engconst/const.htm

${ }^{6}$ Translation by the author

${ }^{7}$ http://www.anayasa.gov.tr/engconst/const.htm

${ }^{8}$ ibid.

${ }^{9}$ ibid.

${ }^{10}$ ibid.

${ }^{11}$ For the same debate see Craig P, De Burca G, EU LAW, Texts, Cases \& Materials. Oxford University Press, 2003 Third Edition 
${ }^{12}$ See the view of Craig De Burca in EC Law Texts, Cases\&Materials, Oxford University Press 1997 p.270. reference to Shields v. Coomes (Holdings) Ltd [1979] 1 All ER 456, 461

${ }^{13}$ Translated by the author

${ }_{15}^{14} \mathrm{http}: / / \mathrm{www}$.anayasa.gov.tr/engconst/const.htm

${ }^{15}$ ibid.

${ }^{16} \mathrm{ibid}$

${ }^{17}$ Translated by the author 